\title{
Membrane Potential of Rat Hepatoma Cells in Culture: Influence of Factors Affecting Amino Acid Transport
}

\author{
M. F. Mouat, ${ }^{3,4}$ A. C. Cantrell, ${ }^{2}$ and \\ K. L. Manchester ${ }^{1}$
}

Received January 2, 1995; accepted August 4, 1995

\begin{abstract}
The effect has been studied of various media, hormones and of amino acids on the membrane potential of rat hepatoma cells in culture measured by microelectrode impalement. Cells in Eagle's minimal essential medium plus $5 \%$ serum had a value which varied daily from about $5-8 \mathrm{mV}$, inside negative. The membrane potential of rat hepatocytes was measured to be $8.7 \pm 0.2 \mathrm{mV}$, inside negative. The membrane potential of the hepatoma cells was decreased by insulin and increased by glucagon. Membrane potential was unaffected by change of medium to Hanks' or Earle's balanced salt solutions or deprivation of serum. It was, however, reduced in cells in phosphate-buffered saline and by reduction of $\mathrm{pH}$. The former effect was shown to be due to the higher $\left[\mathrm{Na}^{+}\right]$of phosphate-buffered saline as opposed to the other media. Addition of alanine, glycine, serine, proline and methylaminoisobutyrate all reduced membrane potential by $2-3 \mathrm{mV}$. Smaller decreases were seen with methionine, leucine and phenylalanine, but none with glutamine, threonine, $\mathrm{BCH}$ (2-aminonorborane-2-carboxylic acid) and D-alanine. The results are compared with the effects of similar conditions on aminoisobutyrate uptake. Whilst there was a correlation under some conditions there was not under others. It is concluded that for the hepatoma celis factors additional to the membrane potential must exert some influence on the capacity for amino acid transport.
\end{abstract}

KEY WORDS: microelectrode; sodium ion; aminoisobutyrate uptake.

\section{INTRODUCTION}

The uptake of many amino acids by animal cells is $\mathrm{Na}^{+}$-dependent (Christensen et al., 1973; Shotwell et al., 1983; Leister et al., 1988). The membrane potential contributes to the electrochemical gradient of the $\mathrm{Na}^{+}$ion and it is well

\footnotetext{
${ }^{1}$ Department of Biochemistry, University of the Witwatersrand.

${ }^{2}$ National Centre for Occupational Health, Johannesburg 2001, South Africa.

${ }^{3}$ Department of Human Ecology, The University of Texas at Austin, Austin, Texas 78712-1097, USA.

${ }^{4}$ To whom correspondence should be addressed.
} 
established that $\mathrm{Na}^{+}$-dependent uptake of amino acids is electrogenic and lowers the membrane potential (Heinz et al., 1975; Laris et al., 1976; Philo and Eddy, 1978a,b; Bergman and Bergman, 1981; Smith et al., 1982; Pershadsingh et al., 1985).

Amino acid transport has been deemed to be accomplished by a number of distinctive systems of mediation with specific properties (Christensen et al., 1973; Christensen, 1979; Shotwell et al., 1983; Leister et al., 1988). Amino acid transport by System $\mathrm{A}$ is characterised by its $\mathrm{Na}^{+}$-dependence while that by System $\mathrm{L}$ is $\mathrm{Na}^{+}$-independent. Membrane potential has been implicated as a factor in amino acid transport for Ehrlich ascites tumour cells (Philo and Eddy, 1978a; Pershadsingh et al., 1978; Johnstone, 1978; Burckhardt and Pietrzyk, 1980) and for plasma membrane vesicles from (i) transformed mouse fibroblasts (Lever, 1977) and (ii) rat liver (Sips et al., 1980). However, the extent and importance of the involvement of the membrane potential in amino acid transport is uncertain, although a definite and important contribution towards System A transport has been suggested for normal and transformed mouse fibroblasts (Leister et al., 1988).

In previous experiments from this laboratory the influence of a variety of media and of various amino acids on the ability of rat hepatoma cells to accumulate the model amino acid aminoisobutyrate, whose uptake is $\mathrm{Na}^{+}$dependent, has been studied (Grimm and Manchester, 1976; Gulumian and Manchester, 1981). Culture of the cells without serum, change of ionic conditions of the medium, and addition of various amino acids including the model amino acid $\mathrm{BCH}$ (2-aminonorbornane-2-carboxylic acid), whose uptake is $\mathrm{Na}^{+}$independent, were all found to affect aminoisobutyrate accumulation. This study investigates the extent to which the factors changing the rate of aminoisobutyrate uptake likewise influence the membrane potential of the cells.

\section{MATERIALS AND METHODS}

\section{Hepatoma Cell Culture}

The composition of media used and the culturing of the cells was as described previously (Gulumian and Manchester, 1981). Rat hepatoma cells, originally derived by treatment of rats with 3-methyl-4-dimethylaminoazobenzene (Albrecht et al., 1973), were grown in Eagle's minimal essential medium with glutamine (MEM) plus 5\% foetal calf serum (FCS). The cells were cultured as monolayers in $50 \mathrm{ml}$ plastic tissue culture flasks (Nunclon) which had a surface area of $25 \mathrm{~cm}^{2}$. Incubation of the cells was at $37^{\circ} \mathrm{C}$ in air. The cells were subcultured by trypsinization at weekly intervals and the medium was changed every four days. Cells were counted with a haemocytometer; their viability was estimated by trypan blue exclusion to be $90-94 \%$. Because these cells had been 
through a large number of passages, they were highly adapted to their culturing conditions.

\section{Membrane Potential Measurements}

For measurement of membrane potential by microelectrode impalement it was necessary to attach cells to glass coverslips for compatibility with the experimental apparatus. Cells were collected by trypsinization $20 \mathrm{~h}$ after change of culture medium. This corresponded to the stage when the cells were previously subjected to amino acid transport studies (Gulumian and Manchester, 1981). To facilitate the taking of good membrane potential measurements the cells were transferred at a suitable density, i.e. about $0.5 \times 10^{6}$ cells $/ \mathrm{ml}$, to culture flasks containing coverslips. The cell density was not too high that the cells would impede movement of the microelectrode, but was sufficient to allow for quick and efficient measurement-taking. After incubation for $1 \mathrm{~h}$ at $37^{\circ} \mathrm{C}$ in air, attachment of the cells to the coverslips was complete and the cells were ready for electrode measurements. Any adverse effect of trypsinisation on the membrane potential had been overcome as judged by measurements $24 \mathrm{~h}$ after trypsinisation which were the same as those $1 \mathrm{~h}$ afterwards. At this stage ( $24 \mathrm{~h}$ after trypsinisation), however, the cell density was very high because of cell division and therefore measurement-taking was difficult and inefficient. For this reason the membrane potential was measured after a $1 \mathrm{hr}$ incubation.

Microelectrodes, prepared by pulling a combined glass capillary and blank on a commercial electrode puller (C. F. Palmer, model 418/8115: Bioscience), were filled with $2.5 \mathrm{M} \mathrm{KCl}$ and each had an $\mathrm{Ag} / \mathrm{AgCl}$ wire inserted. Microelectrodes with resistances of 58-98 M 2 , as measured on a rapid-response apparatus designed for the purpose, were selected for measurements. The sample bath, containing the coverslip with adhered cells, was mounted on the stage of an inverted Zeiss microscope (Invertoscope D). One microelectrode was chosen to be the impaling electrode and was mounted close to the reference electrode on one side of a Leitz micromanipulator. The electrodes were connected to the input of a preamplifier, the signal from which was fed into a Tektronix $5103 \mathrm{~N}$ storage oscilloscope.

A membrane potential measurement was taken to be valid and recorded when the following criteria had been met: (a) a rapid potential change, as indicated by the trace of the oscilloscope and occurring within about $0.5 \mathrm{~s}$, on inserting the electrode into the cell, (b) a peak then being reached which was free of noise and stable for several seconds, and (c) the immediate return of the trace to the base line on withdrawal of the electrode. Our apparatus was capable of recording any transient (occurring in less than $1 \mathrm{~ms}$ ) change in the membrane potential. Although it has been reported that the membrane potential on microelectrode penetration of Ehrlich ascites tumour cells decays within $1 \mathrm{~ms}$, presumably as a consequence of the impalement, and then stabilises at an artifactually lower value (Lassen et al., 1971), we could not find any evidence of this occurring with our hepatoma cells. Results were plotted as histograms and statistically evaluated by the $\chi^{2}$ test. 


\section{RESULTS}

\section{Effects of Insulin and Glucagon on Membrane Potential of Rat Hepatoma Cells}

The membrane potential of rat hepatoma cells in MEM plus 5\% foetal calf serum (FCS) varied in successive experiments in the range of 5-8 $\mathrm{mV}$, inside negative. Figure 1 gives photographic records of oscilloscope traces obtained on microelectrode impalement of several cells. Using the same apparatus a value of $11.2 \pm 0.7 \mathrm{mV}$ (31 observations), inside negative, was obtained for rat pulmonary alveolar macrophages (Brenner et al., 1981). For rat hepatocytes adhered to collagen-coated coverslips a value of $8.7 \pm 0.2 \mathrm{mV}$ (50 observations), inside negative, was obtained. A typical histogram of the sort of measurements obtained for the hepatoma cells is shown in Fig. 2. Any particular batch of cells, however, had a stable average membrane potential over the period of an experiment, e.g. values of $6.2,6.4,6.7,6.5$, each \pm 0.3 for 18 observations, were found in a typical case at $60,90,120$ and 150 minutes after transfer to coverslips. Each of the hormones, insulin $\left(3 \times 10^{-7} \mathrm{M}\right)$ and glucagon $\left(10^{-6} \mathrm{M}\right)$ had an effect on the membrane potential of the cells (Table 1). Exposure to insulin resulted in a depolarisation (about $1 \mathrm{mV}$ ), whereas addition of glucagon induced a hyperpolarisation $(2 \mathrm{mV})$. If the cells were incubated with glucagon for $12 \mathrm{~h}$ before

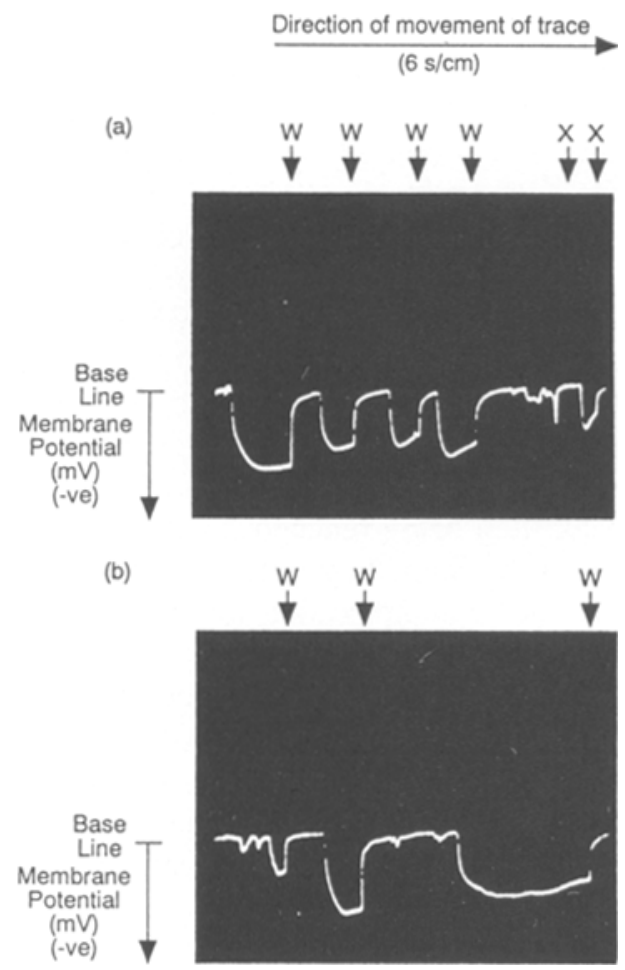

Fig. 1. Oscilloscope trace of membrane potential measurements. For both traces (a) and (b) measurements of membrane potential of rat hepatoma cells were in Eagle's Minimal Essential Medium (MEM) $+5 \%$ serum (FCS). $X$ denotes an unsatisfactory measurement. The point of withdrawal of the electrode from the cell for each of these penetrations is marked by $\mathrm{W}$, after which the trace rapidly returns to the base line. 


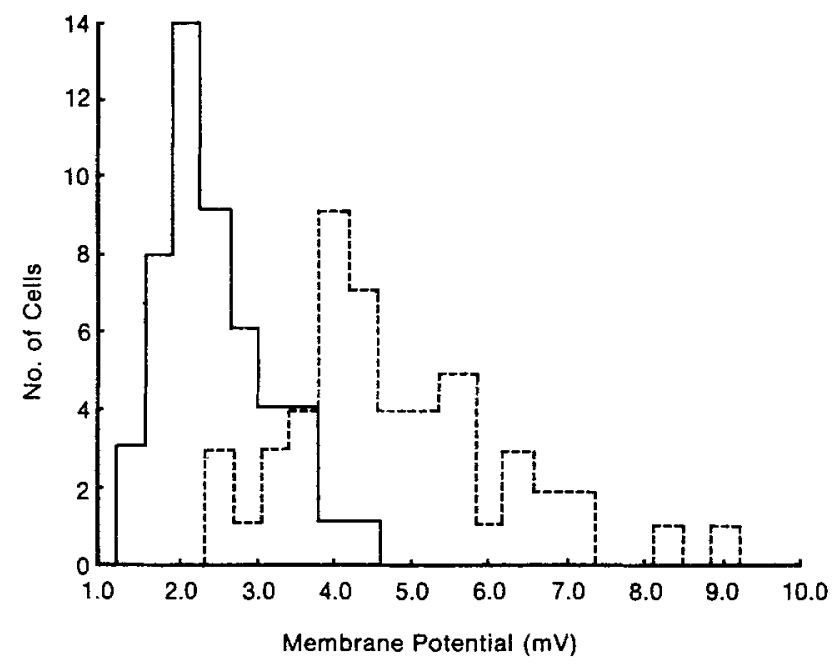

Fig. 2. Comparison of membrane potential of hepatoma cells in phosphate-buffered saline and Hanks' balanced salt solution. Prior to impalement by glass electrodes, cells in MEM $+5 \%$ FCS were allowed to attach to glass coverslips as described in Materials and Methods. The cells were then bathed in each of phosphatebuffered saline and Hanks' balanced salt solution and measurements commenced. The mean \pm SEM in each case was as follows: phosphate-buffered saline (- in figure) $2.6 \pm 0.1 \mathrm{mV}$

Hanks' balanced salt solution (- - - in figure) $4.9 \pm 0.3 \mathrm{mV}$

The number of observations in each medium was 50 .

measuring the membrane potential no effect was seen (Table 1). Insulin stimulates aminoisobutyrate uptake by the hepatoma cells (Grimm and Manchester, 1976). Some rat hepatoma cell lines show no effect of glucagon on aminoisobutyrate uptake (Kelley et al., 1978) in contrast to others (Baril et al., 1969; Reynolds et al., 1971) and to hepatocytes (Kelley et al., 1978; Wondergem and Harder, 1980).

Table 1. Infuence of insulin and glucagon on the membrane potential of hepatoma cells

\begin{tabular}{lccc}
\hline & \multicolumn{2}{c}{ Membrane Potential } & \\
\cline { 2 - 3 } & $\begin{array}{c}\text { Control } \\
(\mathrm{mV})\end{array}$ & $\begin{array}{c}\text { Experiment } \\
(\mathrm{mV})\end{array}$ & $\mathrm{P}$ \\
\hline Hormone & $5.9 \pm 0.2$ & $4.7 \pm 0.2(60)$ & $<0.001$ \\
Insulin $\left(3 \times 10^{-7} \mathrm{M}\right)$ & $8.0 \pm 0.4$ & $10.0 \pm 0.3(42)$ & $<0.001$ \\
Glucagon $\left(10^{-6} \mathrm{M}\right)$ & $7.0 \pm 0.4$ & $7.1 \pm 0.4(61)$ & $\mathrm{NS}$ \\
Glucagon $\left(10^{-6} \mathrm{M}\right)$ & & & \\
$(12$ h incubation $)$ & & & \\
\hline
\end{tabular}

Prior to impalement by glass electrodes, cells in MEM $+5 \%$ FCS were allowed to attach to glass coverslips as described in Materials and Methods. Measurements were commenced in Hanks' balanced salt solution on addition of the hormones. In line 3 the cells were incubated with glucagon in MEM $+5 \%$ FCS for 12 hours before commencing measurements. Each figure is the mean \pm SEM of the number of observations in parenthesis. 
Table 2. Effect of medium $\mathrm{Na}^{+}$concentration on the membrane potential of hepatoma cells

\begin{tabular}{lccc}
\hline Medium & $\begin{array}{c}\mathrm{Na}^{+} \text {concentration } \\
(\mathrm{mmol} / \mathrm{l})\end{array}$ & $\begin{array}{c}\text { Membrane potential } \\
(\mathrm{mV})\end{array}$ & $\begin{array}{c}\mathrm{P} \\
((1) \text { versus (2)) }\end{array}$ \\
\hline (a) (1) Hanks' BSS & 165 & $3.8 \pm 0.1(50)$ & \\
(2) Hanks' BSS & 146 & $6.9 \pm 0.3$ & $<0.001$ \\
(b) (1) Hanks' BSS & 165 & $3.4 \pm 0.2(50)$ & $\mathrm{NS}$ \\
(2) PBS & 165 & $3.0 \pm 0.2(34)$ & \\
(c) (1) PBS & 146 & $5.3 \pm 0.3(30)$ & $\mathrm{NS}$ \\
(2) Hanks' BSS & 146 & $5.4 \pm 0.2$ & \\
\hline
\end{tabular}

The cells in MEM $+5 \%$ FCS were allowed to attach to coverslips as described in Materials and Methods. Membrane potential measurements were commenced once the cells came in contact with medium of a particular concentration of $\mathrm{Na}^{+}$. In each case measurements were completed for two media to enable determination of the comparative effects of the $\mathrm{Na}^{+}$ concentration. Each figure is the mean \pm SEM of the number of observations in parenthesis. Hanks' BSS = Hanks' balanced salt solution

PBS $=$ Phosphate-buffered saline

\section{Effects of Various Media on Membrane Potential of Rat Hepatoma Cells}

When either Hanks' or Earle's balanced salt solution replaced the usual medium (MEM $+5 \% \mathrm{FCS})$ in which membrane potential was measured there was no significant change in potential, nor was potential significantly affected by whether serum was present or not during impalement (results not shown). Cells cultured in MEM without addition of serum for 20 hours preceding their transfer to coverslips likewise had a potential which was not significantly different from that of cells cultured at all times in MEM + serum (results not shown). The effects of these media were studied because earlier work (Gulumian and Manchester, 1981) had shown that aminoisobutyrate uptake was greater in both Hanks' and Earle's balanced salt solutions than in MEM due to lack of competing amino acids in the former. Moreover when cells were cultured for $20 \mathrm{~h}$ preceding uptake measurement in the absence of serum, in either MEM or Hanks' balanced salt solution, there was a marked decrease in aminoisobutyrate uptake.

Bathing the cells in phosphate-buffered saline resulted in a marked drop in potential (Fig. 2) by comparison with that measured in Hanks' balanced salt solution. Gulumian and Manchester (1981) had also found a marked decrease in aminoisobutyrate uptake in phosphate-buffered saline. The result appears to relate to the $\mathrm{Na}^{+}$concentration since when the $\left[\mathrm{Na}^{+}\right]$in Hanks' balanced salt solution was raised to that in phosphate-buffered saline, i.e. from 146 to $165 \mathrm{mM}$, a similar depolarisation of the cells was observed (Table 2, experiments a and b). Moreover lowering of the $\left[\mathrm{Na}^{+}\right]$of phosphate-buffered saline to that in Hanks' balanced salt solution restored the membrane potential to its value in Hanks' balanced salt solution (Table 2, experiment c).

\section{Effect of Medium pH on Membrane Potential of Rat Hepatoma Cells}

Membrane potential was markedly decreased on acidification of the medium, but to a less extent when $\mathrm{pH}$ was increased to 9.0 (Table 3 ). Under the conditions of the experiments viability remained unchanged at each different $\mathrm{pH}$. The 
Table 3. Effect of medium $\mathrm{pH}$ on membrane potential of hepatoma cells

\begin{tabular}{ccc}
\hline $\mathrm{pH}$ & $\begin{array}{c}\text { Membrane potential } \\
(\mathrm{mV})\end{array}$ & $\begin{array}{c}\text { P } \\
\text { (versus value at } \\
\mathrm{pH} \mathrm{7.4)}\end{array}$ \\
\hline 5.2 & $1.0 \pm 0.1(32)$ & $<0.001$ \\
6.8 & $3.0 \pm 0.2(40)$ & $<0.001$ \\
7.4 & $6.0 \pm 0.2(50)$ & - \\
7.7 & $5.9 \pm 0.3(50)$ & $\mathrm{NS}$ \\
9.0 & $5.2 \pm 0.3(50)$ & $<0.001$ \\
\hline
\end{tabular}

After attachment of the cells to coverslips the cells were bathed in Hanks' balanced salt solution whose $\mathrm{pH}$ had been adjusted to a given value. Membrane potential measurements were commenced immediately. Each figure is the mean $\pm S E M$ of the number of observations in parenthesis.

change in membrane potential thus paralleled the decrease in aminoisobutyrate uptake observed under similar conditions (Gulumian and Manchester, 1981).

\section{Effect of Addition of Various Amino Acids on Membrane Potential of Rat Hepatoma Cells}

Table 4 shows that addition of alanine, glycine, serine, proline and methylaminoisobutyrate all produced drops in the membrane potential in the range of $2-3 \mathrm{mV}$. Smaller but significant decreases $(1 \mathrm{mV})$ were produced by methionine, leucine and phenylalanine, whereas no significant change was seen

Table 4. Influence of various amino acids on the membrane potential of hepatoma cells

\begin{tabular}{|c|c|c|c|}
\hline \multirow[b]{2}{*}{ Amino acid } & \multicolumn{2}{|c|}{ Membrane potential } & \multirow[b]{2}{*}{$\mathrm{P}$} \\
\hline & $\begin{array}{l}\text { Control } \\
(\mathrm{mV})\end{array}$ & $\begin{array}{l}\text { Experiment } \\
(\mathrm{mV})\end{array}$ & \\
\hline Alanine & $6.1 \pm 0.3$ & $4.0 \pm 0.1(50)$ & $<0.001$ \\
\hline Glycine & $5.9 \pm 0.2$ & $2.9 \pm 0.1(60)$ & $<0.001$ \\
\hline Serine & $6.9 \pm 0.3$ & $4.1 \pm 0.1(50)$ & $<0.001$ \\
\hline Proline & $6.5 \pm 0.3$ & $4.1 \pm 0.2(60)$ & $<0.001$ \\
\hline MeAIB & $6.5 \pm 0.2$ & $3.0 \pm 0.1(60)$ & $<0.001$ \\
\hline Methionine & $5.3 \pm 0.2$ & $4.3 \pm 0.2(60)$ & $<0.001$ \\
\hline Leucine & $5.0 \pm 0.2$ & $3.9 \pm 0.1(72)$ & $<0.001$ \\
\hline Phenylalanine & $6.6 \pm 0.3$ & $5.4 \pm 0.2(58)$ & $<0.001$ \\
\hline Glutamine & $5.5 \pm 0.3$ & $5.0 \pm 0.2(70)$ & NS \\
\hline Threonine & $6.1 \pm 0.2$ & $6.3 \pm 0.3(65)$ & NS \\
\hline $\mathrm{BCH}$ & $6.0 \pm 0.2$ & $6.4 \pm 0.2(50)$ & NS \\
\hline \multicolumn{4}{|c|}{$\begin{array}{l}\text { Prior to impalement by glass electrodes, cells in MEM+ } \\
5 \% \text { FCS were allowed to attach to glass coverslips. } \\
\text { Measurements were commenced immediately the cells } \\
\text { came in contact with the various amino acids ( } 5 \mathrm{mM} \text { ) in } \\
\text { Hanks balanced salt solution. Each figure is the mean } \\
\pm \text { SEM of the number of observations in parenthesis. }\end{array}$} \\
\hline
\end{tabular}


on addition of glutamine, threonine and $\mathrm{BCH}$. Alanine, glycine, serine, proline and methylaminoisobutyrate all inhibit uptake of aminoisobutyrate by hepatoma cells, glycine not particularly effectively, but likewise inhibition was observed by methionine, leucine, glutamine, threonine and $\mathrm{BCH}$ (Gulumian and Manchester, 1981). D-Alanine, by contrast with its L-isomer, had no significant effect on the potential (results not shown).

\section{DISCUSSION}

The membrane potential observed for our cells of $5-8 \mathrm{mV}$, inside negative, is low, but such low values of membrane potential for mammalian cells are not unique in that from the Nernst distribution of chloride the membrane potential of erythrocytes is $7 \mathrm{mV}$, inside negative (Herrman and Muiller, 1986). From microelectrode measurements, bone cells have also been shown to have low membrane potentials in the range of $5-10 \mathrm{mV}$, inside negative (Ferrier and Ward, 1986). Our value for rat hepatocytes, adhered to collagen-coated coverslips, was $8.7 \pm 0.2 \mathrm{mV}$, inside negative. Rat hepatocytes have elsewhere been shown to sustain a low membrane potential of $10 \mathrm{mV}$, inside negative, in primary monolayer culture (Wondergem, 1983). While a much greater value of $78 \pm 9 \mathrm{mV}$, inside negative, has subsequently been measured by microelectrode impalement (Petzinger and Bigalke, 1986), more recently a membrane potential much lower than this of $25 \pm 0.1 \mathrm{mV}$, inside negative, has been measured using the same technique (Bear et al., 1988) which suggests that the membrane potential of rat hepatocytes may be influenced by as yet unknown factors. Though low, we believe our figure for rat hepatoma cells to represent a genuine value-criteria governing valid membrane potential measurements (see Materials and Methods) were rigidly adhered to and consistent measurements were obtained. Moreover, several treatments induced significant and rational change in the potential. Furthermore, application of the same technique, using the same apparatus, to the measurement of the membrane potential of rat pulmonary alveolar macrophages resulted in a value of $11 \mathrm{mV}$, inside negative, being obtained (Brenner et al., 1981).

We note that the membrane potential of our rat hepatocytes was greater (more negative) than that of the rat hepatoma cells. A similar situation was found for such cells by others (Binggeli and Cameron, 1980) and together with the greater membrane potential of mouse corneal fibroblasts compared with cells of mouse fibrosarcoma this has lent support to the notion that lower membrane potentials may play a significant role in the altered physiology of the tumour cell.

An interesting finding is that the depolarisation of the rat hepatoma cells in phosphate-buffered saline is due to the $\mathrm{Na}^{+}$concentration in this medium being higher than that in Hanks' balanced salt solution. This is indicative of the importance of the $\mathrm{Na}^{+}$diffusion potential in the creation of the resting membrane potential.

Insulin depolarised the rat hepatoma cells and it has also been shown to have such an effect on rat hepatocytes by Wondergem $(1981 ; 1983)$ who has suggested 
that this results from a decrease in membrane $\mathrm{K}^{+}$conductance. The lowering of the membrane potential of the hepatoma cells by insulin correlates inversely with its observed effect, i.e. a stimulation, on aminoisobutyrate uptake (Grimm and Manchester, 1976). Glucagon $\left(10^{-6} \mathrm{M}\right)$ hyperpolarised the hepatoma cells, though not if the cells had been exposed to it for $12 \mathrm{~h}$ prior to measurements. In rat hepatocytes glucagon has been found to elicit a marked hyperpolarisation $12 \mathrm{~h}$ after addition to the cells (Wondergem and Harder, 1980).

Glucagon was observed to have no effect on aminoisobutyrate uptake by several hepatoma cell lines (Kelley et al., 1978) which does not correlate with its effect, determined here, on the membrane potential of hepatoma cells.

With regard to the lack of influence of serum on the membrane potential of hepatoma cells, our cells require serum for growth and division and there is a well established correlation of increased aminoisobutyrate uptake in growing as opposed to quiescent (serum-deprived) cells (Grimm and Manchester, 1976; Gulumian and Manchester, 1981). Thus not all membrane related phenomena, even when induced by an agent as potent as serum, may affect membrane potential. The effect of $\mathrm{pH}$ on membrane potential is similar to that observed by others (Johnstone, 1978; Friedhoff and Sonenberg, 1983), but the cause is not known although it may be a consequence of intracellular acidification (Bear et al., 1988). A direct correlation appears to exist between the effect of $\mathrm{pH}$ on membrane potential and on aminoisobutyrate uptake by the hepatoma cells (Gulumian and Manchester, 1981). Likewise there is a direct correlation between the effect of phosphate-buffered saline on membrane potential and on aminoisobutyrate uptake (Gulumian and Manchester, 1981).

The depression of membrane potential on addition of a variety of amino acids each at a concentration of $5 \mathrm{mM}$ mirrors observations of others (Laris et al., 1976; Philo and Eddy, 1978a,b; Hacking and Eddy, 1981; Bergman and Bergman, 1981; Smith et al., 1982; Pershadsingh et al., 1985) which have been ascribed to the coupling of $\mathrm{Na}^{+}$to amino acid uptake, i.e. a $\mathrm{Na}^{+}$symport underlies the depression of membrane potential observed with certain amino acids the uptake of which is thus electrogenic. The depolarisation of the cells has been shown to be effected by amino acids such as leucine, isoleucine, phenylalanine and tryptophan (Table 3 and Philo and Eddy, 1978a,b; Hacking and Eddy 1981) where uptake is believed to be primarily by System L. The findings imply that a significant portion of the uptake of these latter amino acids must also be $\mathrm{Na}^{+}$-dependent, i.e. by System A and/or ASC. Lack of influence of BCH was also observed by Hacking and Eddy (1981), but the inactivity of glutamine and threonine was unexpected in the light of previous findings with these amino acids (Laris et al., 1976; Bergman and Bergman, 1981).

One of the aims of this work was to attempt a correlation of circumstances in which an increase or decrease in aminoisobutyrate uptake correlates with a change in membrane potential. Clearly such a correlation is incomplete and inconsistent, but does exist for certain conditions. While there were correlations with the effects of $\mathrm{pH}$ and phosphate-buffered saline, for serum deprivation of the cells a correlation was not obtained. In the case of the effects of insulin, an inverse correlation was obtained. Insulin may thus exert an influence on System 
A amino acid transport which is independent of the influence of membrane potential. Similarly, the peptide hormones or growth factors present in serum may stimulate amino acid transport without affecting the membrane potential. The effect of the hormones or growth factors may be a stimulation of the activity and/or synthesis of System A amino acid transport carriers. This suggests $\mathrm{Na}^{+}$-dependent amino acid uptake is not mediated solely through the membrane potential although under physiological conditions this would have a role as indicated by the results obtained here. There is evidence for the existence of multiple mechanisms of regulation of System A amino acid transport in a kidney epithelial cell line (Boerner and Saier, 1988). Thus, while the results indicate a participation of the membrane potential in active, $\mathrm{Na}^{+}$-dependent, amino acid transport, the incomplete and inconsistent correlation of the potential with aminoisobutyrate uptake under different conditions suggests the involvement of supplementary factors. These factors may be linked to the metabolic activity of the cell which may influence the activity, possibly through provision of energy, and/or synthesis of the carrier proteins for amino acid transport. Evidence has been provided for the regulation of hepatic System A aminto acid transport via transcriptional and translational control mediated by hormones or growth factors, of synthesis of plasma membrane carrier proteins (Kilberg, 1986).

Glutamine can be distinguished from the other amino acids since its uptake is believed to proceed mainly via a unique pathway, System N. Although this pathway has been found to be $\mathrm{Na}^{+}$-dependent (Kilberg et al., 1980), if in our cells it were to be driven by other metabolic activity the lack of its influence on membrane potential might be explained.

In the earlier transport studies in this laboratory (Gulumian and Manchester, 1981) $\mathrm{BCH}$ was found to inhibit uptake of aminoisobutyrate. In view of the lack of effect of $\mathrm{BCH}$ on the membrane potential one must conclude that it is not being taken up significantly by System A mediation. Its inhibitory effect on aminoisobutyrate uptake could still result from a variety of circumstances, e.g. if aminoisobutyrate also uses System $\mathrm{L}$ as well as $\mathrm{A}$ as has been reported for several cell types (Christensen, 1979; Kilberg et al., 1979), or if BCH were to bind to the $\mathrm{Na}^{+}$gradient-driven carrier but form a complex incapable of transport, thus inhibiting the system. The behaviour of threonine is similarly explicable.

\section{ACKNOWLEDGEMENTS}

This work was supported by the South African Council for Scientific and Industrial Research.

\section{REFERENCES}

Albrecht, C. F., Liebenberg, N. v. d. W. and Theron, J. J. (1973) The ultra-structure of a transplantable rat hepatoma induced by 3'-methyl-4-dimethylaminoazobenzene. S. Afr. J. Med. Sci., 37:91-94.

Baril, E. F., Potter, V. R. and Morris, H. P. (1969) Amino acid transport in rat liver and Morris 
hepatomas: effect of protein diet and hormones on the uptake of $\alpha$-aminoisobutyric acid- ${ }^{14} \mathrm{C}$. Cancer Res., 29:2101-2115.

Bear, C. E., Davison, J. S. and Shaffer, E. A. (1988) Intracellular $\mathrm{pH}$ influences the resting membrane potential of isolated rat hepatocytes. Biochim. Biophys. Acta, 944:113-120.

Bergman, C. and Bergman, J. (1981) Electrogenic responses induced by neutral amino acids in endoderm cells from Xenopus embryo. J. Physiol., 318:259-278.

Binggeli, R. and Cameron, I. L. (1980) Cellular potentials of normal and cancerous fibroblasts and hepatocytes. Cancer Res., 40:1830-1835.

Boerner, P. and Saier, M. H. (Jr.) (1988) Effects of 5-azacytidine, sodium butyrate, and phorbol esters on amino acid transport System A in a kidney epithelial cell line, MDCK: evidence for multiple mechanisms of regulation. J. Cell. Physiol., 137:117-124.

Brenner, E. A., Manchester, K. L., Webster, I. and Cantrell A. C. (1981) Attempts to demonstrate short-term metabolic effects of vinyl chloride in normal rat liver. Am. J. Ind. Med., 2:153-159.

Burckhardt, G. and Pietrzyk, C. (1980) The infuence of an uncoupler on amino acid accumulation in Ehrlich mouse ascites tumour cells. Biochim. Biophys. Acta, 601:403-414.

Christensen, H. N. (1979) Exploiting amino acid structure to learn about membrane transport. Adv. Enzymol., 49:41-101.

Christensen, H. N., de Cespedes, C., Handlogten, M. E. and Ronquist, G. (1973) Energisation of amino acid transport, studied for the Ehrlich ascites tumour cell. Biochim. Biophys. Acta, 300:487-522.

Ferrier, J. and Ward, A. (1986) Electrophysiological differences between bone cell clones: membrane potential responses to parathyroid hormone and correlation with the cAMP response. J. Cell. Physiol., 126:237-242.

Friedhoff, L. T. and Sonenberg, M. (1983) The membrane potential of human platelets. Blood, 61: $180-185$.

Grimm, J. and Manchester, K. L. (1976) Influence of serum and insulin on the accumulation of aminoisobutyrate by rat hepatoma cells. Biochim. Biophys. Acta, 444:223-230.

Gulumian, M. and Manchester, K. L. (1981) Influence of serum and amino acids on the accumulation of aminoisobutyrate by rat hepatoma cells. A dedifferentiation of transport routes? Biochim. Biophys. Acta, 649:24-30.

Hacking, C. and Eddy, A. A. (1981) The accumulation of amino acids by mouse ascites-tumour cells. Biochem. J., 194:415-426.

Heinz, E., Geck, P. and Pietrzyk, C. (1975) Driving forces of amino acid transport in animal cells. Ann. N.Y. Acad. Sci., 264:428-441.

Herrmann, A. and Müller, P. (1986) Ionic strength-dependent alterations or membrane structure of red blood cells. Biosci. Rep., 6:1007-1015.

Johnstone, R. M. (1978) The hyperpolarising and depolarising effects of 2,4-dinitrophenol on Ehrlich cells. Biochim. Biophys. Acta, 512:550-556.

Kelley, D. S., Becker, J. E. and Potter, V. R. (1978) Effect of insulin, dexamethasone and glucagon on the amino acid transport ability of four rat hepatoma cell lines and rat hepatocytes in culture. Cancer Res., 38:4591-4600.

Kilberg, M. S. (1986) System A-mediated amino acid transport: metabolic control at the plasma membrane. Trends Biochem. Sci., 11:183-186.

Kilberg, M. S., Christensen., H. N. and Handlogten, M. E. (1979) Cysteine as a system-specific substrate for transport system ASC in rat hepatocytes. Biochem. Biophys. Res. Commun., 88: 744-751.

Kilberg, M. S., Handlogten, M. E. and Christensen, H. N. (1980) Characteristics of an amino acid transport system in rat liver for glutamine asparagine, histidine and closely related analogs. $J$. Biol. Chem., 255:4011-4019.

Laris, P.C., Pershadsingh, H. A. and Johnstone, R. M. (1976) Monitoring membrane potentials in Ehrlich ascites tumour cells by means of a fluorescent dye. Biochim. Biophys. Acta, 436:475-488.

Lassen, U. V., Nielsen, A.-M. T., Pape, L. and Simonsen, L. O. (1971) The membrane potential of Ehrlich ascites tumour cells. Microelectrode measurements and their critical evaluation. $J$. Membr. Biol., 6:269-288.

Leister, K. J., Schenerman, M. A. and Racker, E. (1988) Energetic mechanism of System A amino acid transport in normal and transformed mouse fibroblasts. J. Cell Physiol., 135:163-168.

Lever, J. E. (1977) Neutral amino acid transport in surface membrane vesicles isolated from mouse fibroblasts: intrinsic and extrinsic models of regulation. J. Supramol. Structure., 6:103-124.

Pershadsingh, H. A., Johnstone, R. M., and Laris, P. C. (1978) Influence of (DL)-propranolol and $\mathrm{Ca}^{2+}$ on membrane potential and amino acid transport in Ehrlich ascites tumour cells. Biochim. Biophys. Acta, 509:360-373. 
Pershadsingh, H. A., Stubbs, E. B. (Jr.), Noteboom, W. D., Vorbeck, M. L. and Martin, A. P. (1985) Influence of $\mathrm{Ca}^{2+}$ on the membrane potential and electrogenic uptake of glycine by myeloma cells. Involvement of a $\mathrm{Ca}^{2+}$-activated $\mathrm{K}^{+}$channel. Biochim. Biophys. Acta, 821:445-452.

Petzinger, E. and Bigalke, H. (1986) Microelectrode measurement of cell membrane potential in isolated hepatocytes attached to collagen. Biochim. Biophys. Acta, 863:318-324.

Philo, R. D. and Eddy, A. A. (1978a) The membrane potential of mouse ascites-tumour cells studied with the fluorescent probe 3,3'-dipropyl-oxadicarbocyanine. Biochem. J., 174:801-810.

Philo, R. D. and Eddy, A. A. (1978b) Equilibrium and steady-state models of the coupling between the amino acid gradient and the sodium electrochemical gradient in mouse ascites-tumour cells. Biochem. J., 174:811-817.

Reynolds, R. D., Scott, D. F., Potter, V. R. and Morris, H. P. (1971) Further studies on the induction of tyrosine aminotransferase in Morris Hepatoma 9618A. Adv. Enzyme Regul., 9:335-347.

Shotwell, M. A., Kilberg, M. S. and Oxender, D. L. (1983) The regulation of neutral amino acid transport in mammalian cells. Biochim. Biophys. Acta, 737:267-284.

Sips, H. J., van Amelsvoort, J. M. M. and Van Dam, K. (1980) Amino-acid transport in plasma membrane vesicles from rat liver. Characterisation of L-alanine transport. Eur. J. Biochem., 105:217-224.

Smith, T. C., Dawson, W. D. and Robinson, S. C. (1982) Effects of $\alpha$-aminoisobutyric acid on passive $\mathrm{K}^{+}$movements and membrane potential in Ehrlich ascites tumour cells. J. Gen. Physiol., 80:24a.

Wondergem, R. and Harder, D. R. (1980) Transmembrane potential and amino acid transport in rat hepatocytes in primary monolayer culture. J. Cell. Physiol., 104:53-60.

Wondergem, R. (1981) Effect of insulin on transmembrane potential and rubidium efflux from rat hepatocytes in primary monolayer culture. Fed. Proc., 40:368.

Wondergem, R. (1983) Insulin depolarisation of rat hepatocytes in primary monolayer culture. Am. J. Physiol., 244:C17-C23. 